\title{
Calcium-activated Chloride Conductance in Frog Olfactory Cilia
}

\author{
Steven J. Kleene and Robert C. Gesteland \\ Department of Anatomy and Cell Biology, University of Cincinnati, Cincinnati, Ohio 45267-0521
}

\begin{abstract}
We have measured the effects of cytoplasmic $\mathrm{Ca}^{2+}$ on the conductance of single cilia excised from frog olfactory receptor neurons. When free cytoplasmic $\mathrm{Ca}^{2+}$ is buffered at $0.1 \mu \mathrm{M}$, ciliary conductance is low. As $\mathrm{Ca}^{2+}$ is increased, ciliary conductance increases. Maximal conductance averages sevenfold higher than that measured in the absence of $\mathrm{Ca}^{2+}$. We estimate that the $K_{1 / 2}$ for $\mathrm{Ca}^{2+}$ activation is $5 \mu \mathrm{M}$; the dose-response curve indicates some positive cooperativity of $\mathrm{Ca}^{2+}$ binding. Activation by $\mathrm{Ca}^{2+}$ is rapid and fully reversible. Most of the $\mathrm{Ca}^{2+}$-activated current is carried by $\mathrm{Cl}^{-}$and persists in the absence of $\mathrm{Na}^{+}$and $\mathrm{K}^{+}$. The $\mathrm{Cl}^{-}$ channel inhibitor $3^{\prime}, 5$-dichlorodiphenylamine-2-carboxylate $(300 \mu \mathrm{M})$ reduces the $\mathrm{Ca}^{2+}$-activated current by $90 \%$.

Odorants induce a $\mathrm{Ca}^{2+}$ influx in some olfactory receptor neurons, but the consequences of this influx for neuronal function are not well understood. Our findings allow us to predict that a $\mathrm{Ca}^{2+}$ influx would increase the permeability of the olfactory cilia to $\mathrm{Cl}^{-}$. How this would affect the neuronal potential is uncertain, since the equilibrium potential for $\mathrm{Cl}^{-}$ in olfactory receptor neurons is unknown.
\end{abstract}

Olfactory receptor neurons depolarize transiently in response to a wide variety of odorants (reviewed by Getchcll, 1986). Two biochemical mechanisms for this depolarization have strong experimental support. In each mechanism, the olfactory cilia, which protrude from the neuron into the mucus, are believed to be the initial sites of transduction.

cAMP serves as a second messenger in the first mechanism. A large number of odorants have been shown to activate an olfactory adenylate cyclase in vitro (reviewed by Lancet et al., 1988). The product of adenylate cyclase, cAMP, is known to increase the conductance of olfactory cilia (Nakamura and Gold, 1987; Kleene and Gesteland, 1991). The cAMP-activated conductance has a reversal potential near $0 \mathrm{mV}$, and so its activation depolarizes the neuron (Suzuki, 1989; Trotier et al., 1989; Kurahashi, 1990; Firestein et al., 1991).

A second model of olfactory transduction may account for the actions of odorants that do not activate adenylate cyclase in vitro. It is believed that stimulation with some odorants causes an increase in intracellular $\mathrm{Ca}^{2+}$ in olfactory receptor neurons. In catfish (Restrepo et al., 1990) and bullfrog (Sato et al., 1991),

\footnotetext{
Received Apr. 30, 1991; revised June 18, 1991; accepted June 27, 1991.

We are grateful to Shirley Bryant, John Cuppoletti, Carl Johnson, Danuta Malinowska, and Raymund Pun for helpful discussions and/or critical review of the manuscript. This work was supported by National Institutes of Health Grants PO1 DC00347 and RO1 DC00352.

Correspondence should be addressed to Steven J. Kleene, University of Cincinnati, Department of Anatomy and Cell Biology, ML 521, Cincinnati, OH 45267-0521.

Copyright (C) 1991 Society for Neuroscience $0270-6474 / 91 / 113624-06 \$ 05.00 / 0$
}

an odorant-stimulated $\mathrm{Ca}^{2+}$ influx has been directly demonstrated. Odorants can also cause an increase in intraciliary phosphoinositide turnover (Huque and Bruch, 1986; Breer and Boekhoff, 1991). Inositol trisphosphate has been shown to activate a $\mathrm{Ca}^{2+}$ channel from the ciliary membrane of catfish olfactory neurons (Restrepo et al., 1990), which could contribute to the $\mathrm{Ca}^{2+}$ influx. Passage of $\mathrm{Ca}^{2+}$ through the cAMP-activated conductance (Kolesnikov et al., 1990) could also contribute. The $\mathrm{Ca}^{2+}$ influx itself could depolarize the neuron. Alternatively, activation of ciliary adenylate cyclase by $\mathrm{Ca}^{2+}$ and calmodulin (Anholt and Rivers, 1990) could cause depolarization as described for the first model.

The precise role played by intracellular $\mathrm{Ca}^{2+}$ in olfactory transduction is unclear and perhaps species dependent. Application of calcium channel blockers to frog olfactory epithelium inhibits the electroolfactogram (Winegar et al., 1988). In frog (Leveteau et al., 1989; other references cited therein) and cattish (Restrepo et al., 1990), removal of extracellular $\mathrm{Ca}^{2+}$ abolishes the electroolfactogram. In newt, however, the slow odorant response survives removal of $\mathrm{Ca}^{2+}$. In fact, the response fails to inactivate unless extracellular $\mathrm{Ca}^{2+}$ is provided (Kurahashi and Shibuya, 1990). Thus, in different species, increases in intracellular $\mathrm{Ca}^{2+}$ have been implicated in both activation and inactivation of the odorant response.

$\mathrm{Ca}^{2+}$ itself activates a variety of membrane channels, and the consequences of an increase in intracellular $\mathrm{Ca}^{2+}$ in olfactory neurons have not been fully determined. We report that addition of cytoplasmic $\mathrm{Ca}^{2+}$ dramatically increases the membrane conductance of frog olfactory cilia. The magnitude of the maximal $\mathrm{Ca}^{2+}$-activated conductance is similar to that activated by cAMP. The $\mathrm{Ca}^{2+}$-activated current is almost entirely carried by $\mathrm{Cl}^{-}$.

\section{Materials and Methods}

Ciliary patch. Single olfactory neurons were isolated from the northern grass frog, Rana pipiens. For each experiment, one cilium of a neuron was sucked into a patch pipette until a high-resistance seal formed near the base of the cilium. By raising the pipette briefly into air, the cilium was excised from the cell. The cilium remained sealed inside the recording micropipette with the cytoplasmic face of the membrane exposed to the bath. The pipette containing the cilium could be quickly transferred through the air to various pseudointracellular baths without rupturing the seal. Complete details have been presented elsewhere (Kleene and Gesteland, 1991).

Solutions. Extracellular solutions were used to bathe intact cells prior to excision of a cilium and to fill the recording pipettes. Standard extracellular solution contained $\mathrm{NaCl}, 115 \mathrm{~mm} ; \mathrm{KCl}, 3 \mathrm{~mm}$; HEPES, 5 $\mathrm{mm} ; \mathrm{MgCl}_{2}, 2 \mathrm{~mm} ; \mathrm{CaCl}_{2}, 1 \mathrm{~mm}$; and $\mathrm{NaOH}, 2 \mathrm{~mm}$ (pH 7.2). For cation replacement, the $\mathrm{NaCl}$ and $\mathrm{KCl}$ were replaced with $118 \mathrm{~mm}$ choline $\mathrm{Cl}$, and the $\mathrm{NaOH}$ with $2 \mathrm{~mm}$ Tris base. The cell suspension was stored in standard extracellular solution. For patch formation, a single cell was transferred to a bath containing whichever of the two extracellular solutions was used to fill the recording pipette.

After a cilium was excised from a neuron, the pipette was lowered into a pseudointracellular solution, which then bathed the cytoplasmic 
Table 1. Apparent association constants (in units of $\mathrm{M}^{-1}$ )

\begin{tabular}{llll} 
& Measured $^{a}$ & \multicolumn{2}{c}{ Calculated $^{b}$} \\
\cline { 4 - 4 } $\mathbf{K}_{\mathrm{Ca}}^{\prime}$ & $\mathrm{K}_{\mathrm{Ca}}^{\prime}$ & $\mathrm{K}_{\mathrm{Mz}^{\prime}}^{\prime}$ \\
\hline BAPTA & & & \\
$\begin{array}{l}\text { Standard pseudointracellular } \\
\text { Cation-replaced pseudointra- } \\
\text { cellular }\end{array}$ & $6,099,000$ & $6,236,000$ & 46.4 \\
& $9,720,000$ & &
\end{tabular}

Dibromo-BAPTA

Standard pseudointracellular

627,000

484,000

7.1

Measured by Scatchard analysis with a $\mathrm{Ca}^{2+}$-selective electrode as described by Bers (1982). Measurements were performed in $115 \mathrm{~mm} \mathrm{KCl}, 5 \mathrm{~mm}$ HEPES, $1 \mathrm{~mm}$ BAPTA or dibromo-BAPTA, and $5 \mathrm{~mm} \mathrm{KOH}(\mathrm{pH} 7.2)$, representing the standard pseudointracellular solution; or $115 \mathrm{~mm}$ choline CI, 5 mм HEPES, 1 mм BAPTA, and $5 \mathrm{~mm}$ Tris base $(\mathrm{pH} 7.2)$, representing the cation-replaced pseudointracellular solution. The portion of the Scatchard plot obtained within the linear range of the $\mathrm{Ca}^{2+}$-selective electrode was fit to a straight line by least-squares regression (Bers, 1982). There was no difference betweeen standard $\mathrm{Ca}^{2+}$ concentration curves determined in the two pseudointracellular solutions.

- Calculated from published constants (Tsien, 1980; Harrison and Bers, 1987) adjusted for our conditions of ionic strength, $\mathrm{pH}$, and temperature as described by Marks and Maxfield (1991). It was assumed that the $\Delta H$ values for binding of $\mathrm{Mg}^{2+}$ to BAPTA and dibromo-BAPTA are the same as for binding to EGTA (Marks and Maxfield, 1991).

membrane of the cilium. Standard pseudointracellular solution contained $\mathrm{KCl}, 110 \mathrm{~mm} ; \mathrm{NaCl}, 5 \mathrm{~mm}$; HEPES, 5 mM; $\mathrm{MgCl}_{2}, 2$ mM; BAPTA or dibromo-BAPTA, $2 \mathrm{mM}$; $\mathrm{KUH}, 9 \mathrm{mM}(\mathrm{pH} 7.2)$; plus various concentrations of free $\mathrm{Ca}^{2+}$ as described. BAPTA [1,2-bis $(o$-aminophenoxy)ethane- $N, N, N^{\prime}, N^{\prime}$-tetraacetic acid] and dibromo-BAPTA [1,2-bis[2bis (o-amino-5-bromophenoxy)ethane- $N, N, N^{\prime}, N^{\prime}$-tetraacetic acid] are highly $\mathrm{Ca}^{2+}$-specific chelators (Tsien, 1980) that served to buffer the concentration of free $\mathrm{Ca}^{2+}$. For cation replacement, the $\mathrm{NaCl}$ and $\mathrm{KCl}$ in the standard solution were replaced with $115 \mathrm{mM}$ choline $\mathrm{Cl}$, and the $\mathrm{KOH}$ with $9 \mathrm{~mm}$ Tris base. For $\mathrm{Cl}^{-}$replacement, the $\mathrm{Cl}$ salts of $\mathrm{K}^{+}$, $\mathrm{Na}^{+}, \mathrm{Mg}^{2+}$, and $\mathrm{Ca}^{2+}$ in the standard solution were replaced with equimolar amounts of their gluconate salts.

Control of free $\mathrm{Ca}^{2+}$ in pseudointracellular solutions. Apparent association constants $K^{\prime}{ }_{\mathrm{Ca}}$ between $\mathrm{Ca}^{21}$ and the chelators BAPTA and dibromo-BAPTA were determined by Scatchard analysis (Bers, 1982) with a Ca2+-specific electrode (Orion 932000). The x-intercept of the Scatchard plot also yielded the true chelator concentration, which was $84-91 \%$ of nominal. The impurity is reportedly water (Harrison and Bers, 1987; Marks and Maxfield, 1991). The measured $K_{C_{a}}^{\prime}$ values are shown in Table 1. For comparison, Table 1 also shows the values obtained when published constants (Tsien, 1980; Harrison and Bers, 1987) are corrected for our conditions of $\mathrm{pH}$, ionic strength, and temperature as described by Marks and Maxfield (1991). In practice, we used the measured values of $K_{\mathrm{Ca}}^{\prime}$ and the calculated values of $K_{\mathrm{Mg}}^{\prime}$. Calcium chloridc solutions were prepared by dilution from a standard $0.1 \mathrm{M}$ solution (Orion 922006) traceable to the National Bureau of Standards. MATHEMATICA software (Wolfram Research Inc.) was used to solve five simultaneous equations for the free $\mathrm{Ca}^{2+}$ and $\mathrm{Mg}^{21}$ concentrations. The five equations are definitions of $K_{\mathrm{Ca}}^{\prime}$ and $K_{\mathrm{Mg}}^{\prime}$ and conservation of species of $\mathrm{Ca}, \mathrm{Mg}$, and chelator. Binding of $\mathrm{Mg}^{2+}$ to the chelator could have been ignored: the calculated free $\mathrm{Mg}^{2+}$ concentration was $2.0 \mathrm{mM}$ in all cases.

Dibromo-BAPTA was the more effective $\mathrm{Ca}^{2+}$ buffer near the $K_{1 b}$ for the conductance we report. Thus, we used dibromo-BAPTA to obtain the dose-response curve (Fig. 1). Since dibromo-BAPTA was only available as the tetrapotassium salt, we used BAPTA to study the doseresponse properties in $\mathrm{Na}^{+}, \mathrm{K}^{+}$-free solutions (see Fig. 3). In preparing a solution intended to have $5 \mu \mathrm{M}$ free $\mathrm{Ca}^{2+}$, a $2 \%$ error in either total $\mathrm{Ca}^{3+}$ or total BAPTA would give a free $\mathrm{Ca}^{2+}$ concentration of 3 or 10 $\mu \mathrm{M}$, depending on the direction of the error. With dibromo-BAPTA, the same errors would give solutions with 4.6 or $5.4 \mu \mathrm{M}$ free $\mathrm{Ca}^{2+}$. A $2 \%$ error in the measured $K_{C a}^{\prime}$ would produce even smaller deviations. In all other experiments, we compared baths containing low (0 or 0.1 $\mu \mathrm{M})$ and high $(300 \mu \mathrm{M})$ free $\mathrm{Ca}^{2+}$. BAPTA was included in both solutions for consistency, although its buffering capacity was exceeded at $300 \mu \mathrm{M}$ free $\mathrm{Ca}^{2+}$.

Electrical recording and data analysis. The recording pipette and
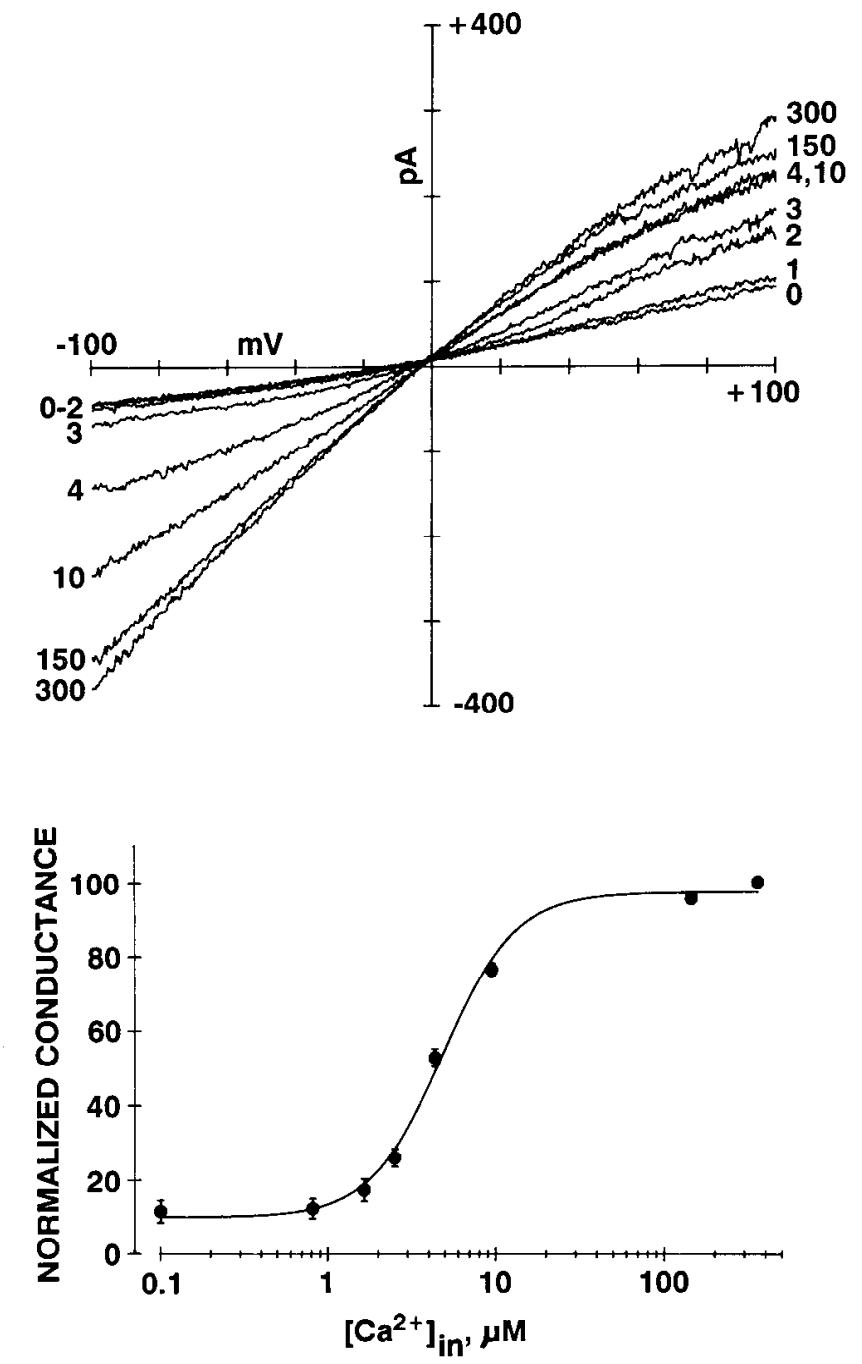

Figure 1. Effect of cytoplasmic $\mathrm{Ca}^{2+}$ on ciliary membrane conductance. Top, The current-voltage relationship of the membrane of one cilium was measured in each of eight baths. Each bath consisted of the standard pseudointracellular solution plus free $\mathrm{Ca}^{2+}$ from 0 to $300 \mu \mathrm{M}$ as indicated. The recording pipette contained standard extracellular solution. Bottom, The slope of the current-voltage plot, measured in the linear range between -50 and $0 \mathrm{mV}$, is plotted against the concentration of free $\mathrm{Ca}^{2+}$ in the bath. Each point is the mean of determinations in seven cilia. Conductance in $300 \mu \mathrm{M} \mathrm{Ca}{ }^{2+}$ was arbitrarily defined as 100 , and the other values were normalized to this. The actual conductance in 300 $\mu \mathrm{M} \mathrm{Ca}^{2+}$ was $4.1 \pm 0.8 \mathrm{nS}(n=7$; range, $1.8-8.3 \mathrm{nS})$. No controls have been subtracted. The curve is the best-fitting Hill equation, which has a $K_{1 / 2}$ of $4.8 \mu \mathrm{M}$ and a Hill coefficient of 2.0 .

chamber were each coupled to a List L/M-EPC7 patch-clamp amplifier by $\mathrm{Ag} / \mathrm{AgCl}$ electrodes. All recordings were done in voltage-clamp mode at room temperature $\left(25^{\circ} \mathrm{C}\right)$. Current was adjusted to zero with the open pipette in the well in which the patching procedure was done; pipette and bath solutions were always identical at this stage. After excision of a cilium, the pipette was transferred through a series of wells containing modified pseudointracellular solutions. Each of these wells was connected by a salt bridge to a common ground bath. The ground bath and salt bridges contained extracellular solution; the salt bridges also included $5 \%(\mathrm{w} / \mathrm{v})$ agarose. Liquid junction potentials between each pseudointracellular bath and its salt bridge were corrected for as described by Hagiwara and Ohmori (1982). Voltage ramps $(+100$ to $-100 \mathrm{mV}$, $0.2 \mathrm{mV} / \mathrm{msec}$ ) and voltage steps were generated by pCLAMP software (Axon Instruments). All records were acquired at a sampling rate of 500 Hz. The shapes of the current-voltage relationships did not vary with the direction of the ramp. 

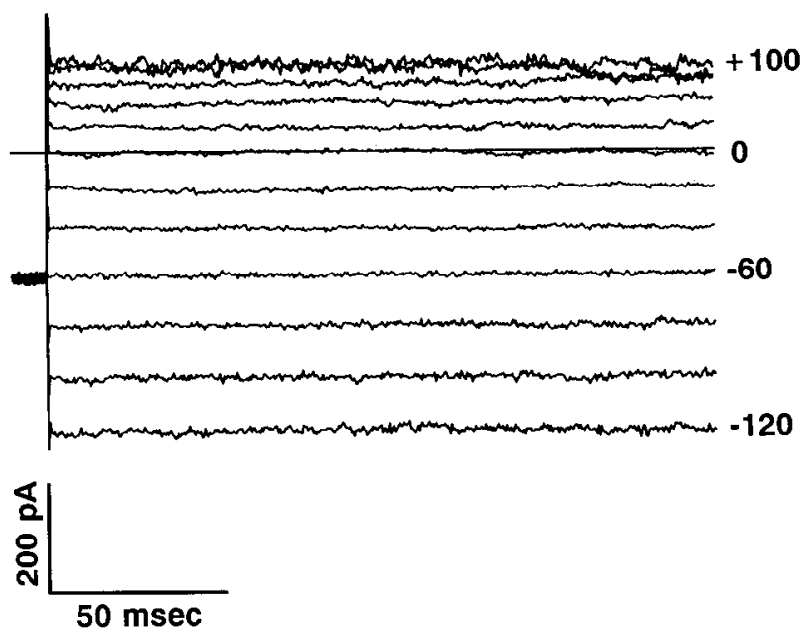

Figure 2. Response of the $\mathrm{Ca}^{2+}$-activated current to voltage steps. Ciliary membrane potential was held at $-60 \mathrm{mV}$ and then stepped to a potential between -120 and $+100 \mathrm{mV}$ as indicated for $200 \mathrm{msec}$. The increment between steps was $20 \mathrm{mV}$ in all cases. The series was performed first in a Ca ${ }^{2+}$-free bath and then in one containing $300 \mu \mathrm{M}$ free $\mathrm{Ca}^{2+}$. The results shown are the records from the second set minus those from the first, that is, the $\mathrm{Ca}^{2+}$-activated current. A solid horizontal line is drawn at $0 \mathrm{pA}$.

In all records, an upward deflection represents increasing positive current from the bath into the pipette. Potentials are reported as bath (cytoplasmic) potential relative to pipette potential. Results of repeated experiments are reported as mean \pm SEM. The absence of an error bar for a plotted point indicates that the SEM was too small to plot or that the point was assigned a value of 100 as indicated in the figure caption. Dose-response curves were fit to a generalized form of the Hill equation (DeLean et al., 1978) using PASSAGE II software (Passage Software, Inc., Fort Collins, $\mathrm{CO}$ ).

The first pseudointracellular bath was always a low- $\mathrm{Ca}^{2+}$ control containing 0 or $0.1 \mu \mathrm{M}$ free $\mathrm{Ca}^{2+}$. The lowest membrane conductance was measured in this situation. At the end of each experiment, the currentvoltage relationship was redetermined in the low-Ca ${ }^{2+}$ bath. If the original low conductance was not measured, we suspected breakdown of the seal or the membrane, and the entire experiment was disregarded.

Chemicals. $\mathrm{Cl}^{-}$channel inhibitors NPPB and DCDPC (see Table 2) were the generous gift of Dr. H.-J. Lang of Hoechst Aktiengesellschaft,

Table 2. Inhibitors of $\mathrm{Ca}^{2+}$-activated ciliary conductance

\begin{tabular}{lrrr} 
Inhibitor $^{a}$ & [inh], $\mu \mathrm{M}$ & \% Inhibition $^{b}$ & $n$ \\
\hline SITS & 100 & $2.2 \pm 2.3$ & 5 \\
DIDS & 100 & $5.1 \pm 2.3$ & 4 \\
A9C & 1000 & $12.5 \pm 2.9$ & 5 \\
DPC & 100 & $20.0 \pm 1.1$ & 5 \\
NPPB & 300 & $32.3 \pm 3.8$ & 4 \\
DCDPC & 300 & $90.4 \pm 1.4$ & 5
\end{tabular}

a Abbreviations: SITS, 4-acetamido-4'-isothiocyanatostilbene-2,2'-disulfonate; DIDS, 4,4'-diisothiocyanatostilbene-2,2'-disulfonate; A9C, anthracene-9-carboxylate; DPC, diphenylamine-2-carboxylate; NPPB, 5-nitro-2-(3-phenylpropylamino)-benzoate; DCDPC, 3',5-dichlorodiphenylamine-2-carboxylate.

${ }^{b}$ For each inhibitor (inh), ciliary slope conductance between -50 and $0 \mathrm{mV}$ was mcasured in threc baths: pscudointracellular solution with no $\mathrm{Ca}^{2+}$, pseudointracellular solution with free $\mathrm{Ca}^{2+}$ elevated to $300 \mu \mathrm{M}$, and the second ( $300 \mu \mathrm{M} \mathrm{Ca}{ }^{2+}$ ) solution plus the indicated concentration of inhibitor. Determinations in the second and third baths were corrected by subtracting the value of the $\mathrm{Ca}^{2+}$-free control (first bath). The percentage reduction of the conductance in the third bath relative to the second (both after correction) is shown. Maximum inhibition was seen within $45 \mathrm{sec}$ in all cases. Standard solutions were used for testing the first four inhibitors, while the cation-replaced versions were used for NPPB and DCDPC. The A9C bath also included $0.5 \%$ (v/v) dimethyl sulfoxide, which alone did not inhibit the ciliary conductance $(n=5)$.

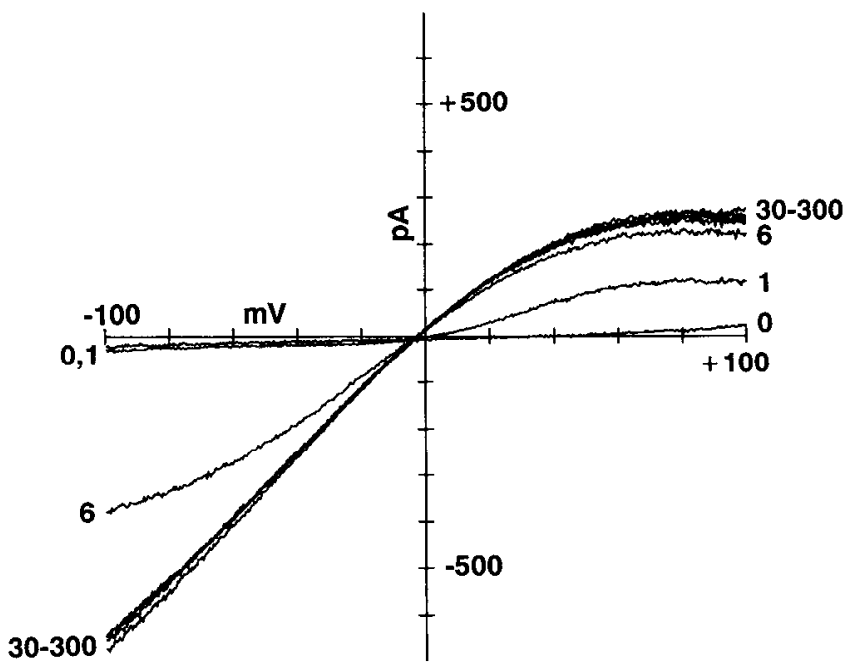

Figure 3. Effect of cytoplasmic $\mathrm{Ca}^{2+}$ on ciliary membrane conductance in the absence of $\mathrm{Na}^{+}$and $\mathrm{K}^{+}$. The current-voltage relationship of the membrane of one cilium was measured in each of seven baths $(0,1,6$, $30,70,110$, and $300 \mu \mathrm{M}$ free $\mathrm{Ca}^{2+}$ ). The baths and recording pipette contained the cation-replaced versions of the pseudointracellular and extracellular solutions, respectively. In each, all $\mathrm{Na}^{+}$and $\mathrm{K}^{+}$were replaced with choline ${ }^{+}$and Tris $^{+}$. The dose-response curve (not shown) from seven such experiments was best fit to a Hill equation with a $K_{1 / 2}$ of $3.2 \mu \mathrm{M}$ and a Hill coefficient of 2.8 .

Frankfurt am Main. DPC was obtained from Hoechst, dibromo-BAPTA from Molecular Probes, and other reagents from Sigma.

\section{Results}

\section{Effects of cytoplasmic $\mathrm{Ca}^{2+}$ on ciliary conductance}

We are able to seal one cilium of an olfactory receptor neuron inside a recording pipette and excise it from the cell. After excision, the cytoplasmic face of the ciliary membrane is exposed to the bath (Kleene and Gesteland, 1991). As a pipette containing a cilium was moved through a series of baths of increasing free $\mathrm{Ca}^{2+}$ concentration, the ciliary membrane conductance increased dramatically (Fig. 1). With the concentration of cytoplasmic free $\mathrm{Ca}^{2+}$ at 0 or $0.1 \mu \mathrm{M}$, the ciliary membrane conductance averaged $0.55 \pm 0.04 \mathrm{nS}$ (slope between -50 and $0 \mathrm{mV} ; n=56$ ). At $2 \mu \mathrm{M} \mathrm{Ca}^{2+}$, the conductance increased at positive potentials. Above $3 \mu \mathrm{M}$, the current also increased at negative potentials. The current-voltage relationship measured with saturating levels of $\mathrm{Ca}^{2+}$ showed some inward rectification. By subtracting the conductance measured between -50 and 0 $\mathrm{mV}$ with no cytoplasmic $\mathrm{Ca}^{2+}$ from that measured with $300 \mu \mathrm{M}$ $\mathrm{Ca}^{2+}$, we determined the magnitude of the maximal $\mathrm{Ca}^{2+}$-activated conductance to be $3.6 \pm 0.2 \mathrm{nS}(n=55$; range, $1.3-7.9$ $\mathrm{nS})$. The reversal potential for the $\mathrm{Ca}^{2+}$-activated current was near $0 \mathrm{mV}$, suggesting that the current was carried either by $\mathrm{Cl}^{-}$, or by a combination of $\mathrm{Na}^{+}$and $\mathrm{K}^{+}$. Half-maximal activation occurred near $5 \mu \mathrm{M} \mathrm{Ca}^{2+}$, and the shape of the dose-response curve indicates some positive cooperativity of $\mathrm{Ca}^{2+}$ binding(Fig. 1). Out of 131 cilia tested, 114 showed the $\mathrm{Ca}^{2+}$-activated increase in conductance.

When a cilium was moved from a low-Ca ${ }^{2+}$ bath to one containing $300 \mu \mathrm{M} \mathrm{Ca}^{2+}$, the higher conductance level was reached within $3 \mathrm{sec}$ and remained stable for at least $10 \mathrm{~min}$ (data not shown). The $\mathrm{Ca}^{2+}$-activated conductance increase was fully reversible. On return to the low-Ca ${ }^{2+}$ bath, the conductance returned to its lower level, again within 3 sec. In $300 \mu \mathrm{M} \mathrm{Ca}^{2+}$, a 
series of voltage steps was applied to the cilium (Fig. 2). The $\mathrm{Ca}^{2+}$-activated current increased rapidly to a stable level at all voltages tested. The new current level was reached within 2 $\mathrm{msec}$, and no inactivation was detected. Inward rectification of the $\mathrm{Ca}^{2+}$-activated current was apparent, as in Figure 1.

\section{$\mathrm{Na}^{+}$and $\mathrm{K}^{+}$independence of the $\mathrm{Ca}^{2+}$-activated ciliary} conductance

In other experiments, we replaced all $\mathrm{Na}^{+}$and $\mathrm{K}^{+}$on both sides of the ciliary membrane with choline ${ }^{+}$and Tris $^{+}$. The $\mathrm{Ca}^{2+}-$ activated conductance was not detectably changed by the elimination of $\mathrm{Na}^{+}$and $\mathrm{K}^{+}$(Fig. 3). In the absencc of $\mathrm{Na}^{+}$and $\mathrm{K}^{+}$, the $\mathrm{Ca}^{2+}$-activated conductance averaged $3.5 \pm 0.2 \mathrm{nS}$ (slope between -50 and $0 \mathrm{mV} ; n=29$; range, $1.0-6.8 \mathrm{nS}$ ). This is not significantly different from the value measured in the standard solutions containing $\mathrm{Na}^{+}$and $\mathrm{K}^{+}$. The inward rectification at saturating $\mathrm{Ca}^{2+}$ levels appears more pronounced in Figure 3 than in Figure 1. This is mostly due to the larger zero- $\mathrm{Ca}^{2+}$ control conductance, with some outward rectification, measured in the standard pseudointracellular solution (Fig. 1, "0").

\section{$\mathrm{Cl}^{-}$dependence of the $\mathrm{Ca}^{2+}$-activated ciliary conductance}

To test the $\mathrm{Cl}^{-}$dependence of the $\mathrm{Ca}^{2+}$-activated conductance, we progressively replaced $\mathrm{Cl}^{-}$in the bath with gluconate ${ }^{-}$(Fig. 4). As $\mathrm{Cl}^{-}$was replaced, the reversal potential of the $\mathrm{Ca}^{2+}$-activated current shifted from $0 \mathrm{mV}$ to negative potentials. When all cytoplasmic $\mathrm{Cl}^{-}$was replaced (Fig. 4, "100\%"), the $\mathrm{Ca}^{2+}$ activated current was not secn to reversc, suggesting that $\mathrm{Cl}^{-}$is the ion primarily responsible for the $\mathrm{Ca}^{2+}$-activated current. The dependence of the reversal potential $V_{r}$ on the log of the transmembrane $\mathrm{Cl}^{-}$concentration ratio can be approximated by a straight line (Fig. 4, bottom). $V_{r}$ shifted $57 \mathrm{mV}$ for each 10 -fold change in cytoplasmic $\mathrm{Cl}^{-}$concentration (Fig. 4), again implicating $\mathrm{Cl}^{-}$as the ion that carries the $\mathrm{Ca}^{2+}$-activated current. (The Nernst equation predicts a $59 \mathrm{mV}$ dependence for a conductance that is perfectly $\mathrm{Cl}^{-}$dependent.) Each measured value of $V_{r}$ was $1-4 \mathrm{mV}$ more positive than the corresponding $\mathrm{Cl}^{-}$equilibrium potential. This could reflect a constant experimental error or a small permeability to an ion with a positive equilibrium potential $\left(\mathrm{Na}^{+}\right.$or $\left.\mathrm{Ca}^{2+}\right)$.

\section{Inhibition of the $\mathrm{Ca}^{3+}$-activated ciliary conductance}

Six $\mathrm{Cl}^{-}$channel inhibitors were tested for their effects on the $\mathrm{Ca}^{2+}$-activatcd ciliary conductance (Table 2). Only one, DCDPC, was a strong inhibitor. It inhibited the $\mathrm{Ca}^{2+}$-activated conductance at all potentials tested (Fig. 5). We estimate that halfmaximal inhibition would occur at $14 \mu \mathrm{M}$ DCDPC. Inhibition by DCDPC was reversed by returning the pipette to a bath containing $300 \mu \mathrm{M} \mathrm{Ca}{ }^{2+}$ but no inhibitor. After $5 \mathrm{~min}$ in this bath, $73 \%$ of the $\mathrm{Ca}^{2+}$-activated current returned; no further recovery was seen at longer times. DPC and the related compounds NPPB and DCDPC have been reported to block not only $\mathrm{Cl}^{-}$channels (Wangemann et al., 1986; Franciolini and Petris, 1990; $\mathrm{Li}$ et al., 1990) but also a Ca ${ }^{2+}$-sensitive nonselective cation channel (Gögelein and Pfannmüller, 1989).

\section{Discussion}

In some olfactory neurons, odorants cause an influx of $\mathrm{Ca}^{2+}$ (Restrepo et al., 1990; Sato et al., 1991). The consequences of elevated intracellular $\mathrm{Ca}^{2+}$ for neuronal function are not fully understood. We report that cytoplasmic $\mathrm{Ca}^{2+}$ has a major effect on the membrane conductance of frog olfactory cilia. In the
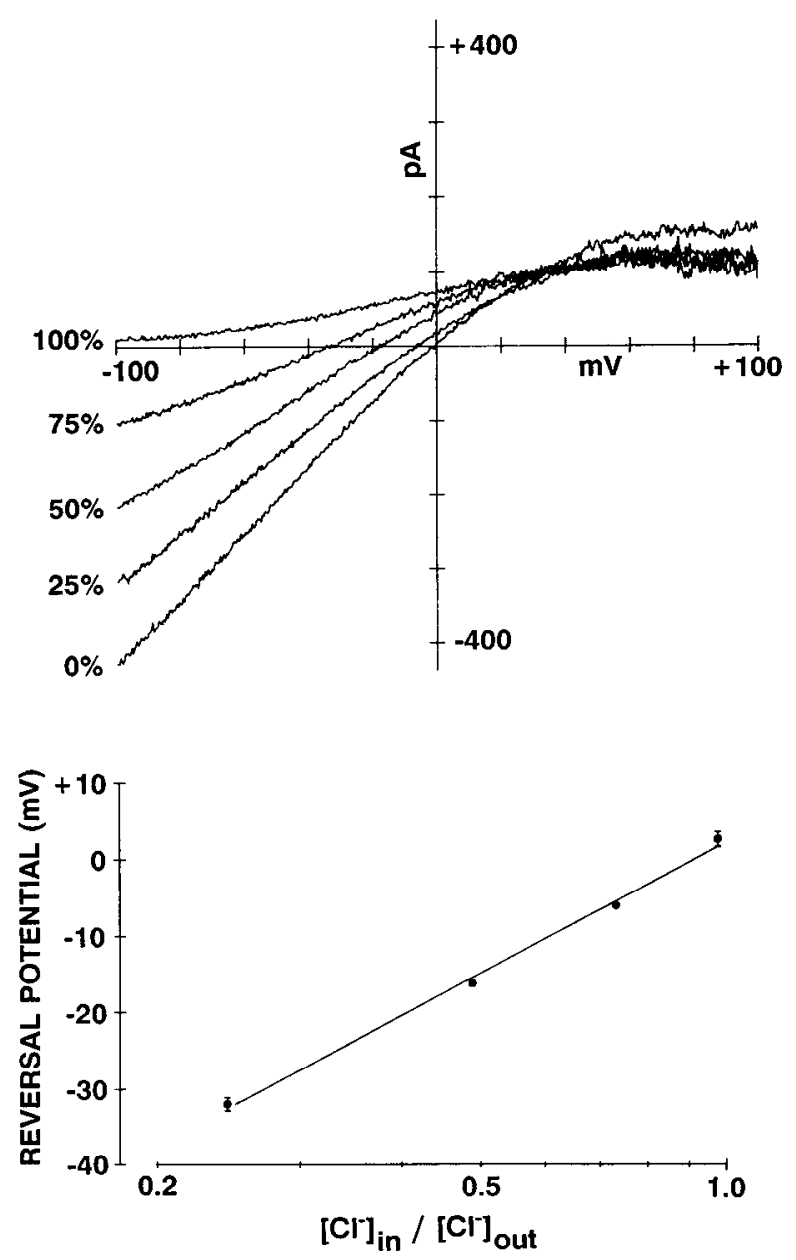

Figure 4. Dependence of the $\mathrm{Ca}^{2+}$-activated conductance on $\mathrm{Cl}^{-}$. Top, The current-voltage relationship of the membrane of one cilium was measured in each of 10 baths. One set of five baths contained $0.1 \mu \mathrm{M}$ free $\mathrm{Ca}^{2+}$; a second set contained $300 \mu \mathrm{M}$ free $\mathrm{Ca}^{2+}$. The results shown are the records from the second set minus those from the first, that is, the $\mathrm{Ca}^{2+}$-activated current. For each pair of baths, the indicated percentage of $\mathrm{Cl}^{-}$was replaced by gluconate- ${ }^{-}$(The solutions were prepared by mixing standard and $\mathrm{Cl}^{-}$-replaced pseudointracellular solutions in ratios of $0: 1,1: 3,1: 1$, etc.) The recording pipette contained standard extracellular solution in all cases. Bottom, The reversal potentials of the current-voltage relationships are plotted against the concentration ratio of $\mathrm{Cl}^{-}$across the ciliary membrane. Each point is the mean \pm SEM of determinations in 6-10 cilia. Control curves measured in $0.1 \mu \mathrm{M}$ free $\mathrm{Ca}^{2+}$ were subtracted as in the example shown at the top. A $20 \mathrm{mV}$ region near the apparent reversal potential of the difference curve was fit to a straight line by lcast-squares regrcssion, and the voltage intercept of this line was taken as the reversal potential. The data were fit to the straight line shown by least-squares regression. The line increases 57 $\mathrm{mV}$ per 10 -fold change in $\mathrm{Cl}^{-}$ratio and has a reversal potential of +2 $\mathrm{mV}$ at a Cl${ }^{-}$ratio of 1 . The maximum $\mathrm{Ca}^{2+}$-activated current (slope of the " $0 \%$ " curve between -50 and $0 \mathrm{mV})$ averaged $3.8 \pm 0.4 \mathrm{nS}(n=$ 10 ; range, $2.0-6.4 \mathrm{nS}$ ).

absence of cytoplasmic $\mathrm{Ca}^{2+}$, the ciliary membrane conductance is low. Addition of cytoplasmic $\mathrm{Ca}^{2+}$ causes an increase in conductance. The maximal increase averages sevenfold, and the current does not inactivate as long as the $\mathrm{Ca}^{2+}$ is present. Apparently the $\mathrm{Ca}^{2+}$-activated current has no requirement for nucleoside triphosphates or calmodulin; these were not included in the pseudointracellular solution. cAMP increases ciliary conductance to a similar extent (Nakamura and Gold, 1987; Kleene and Gesteland, 1991). However, the cAMP-activated conduc- 

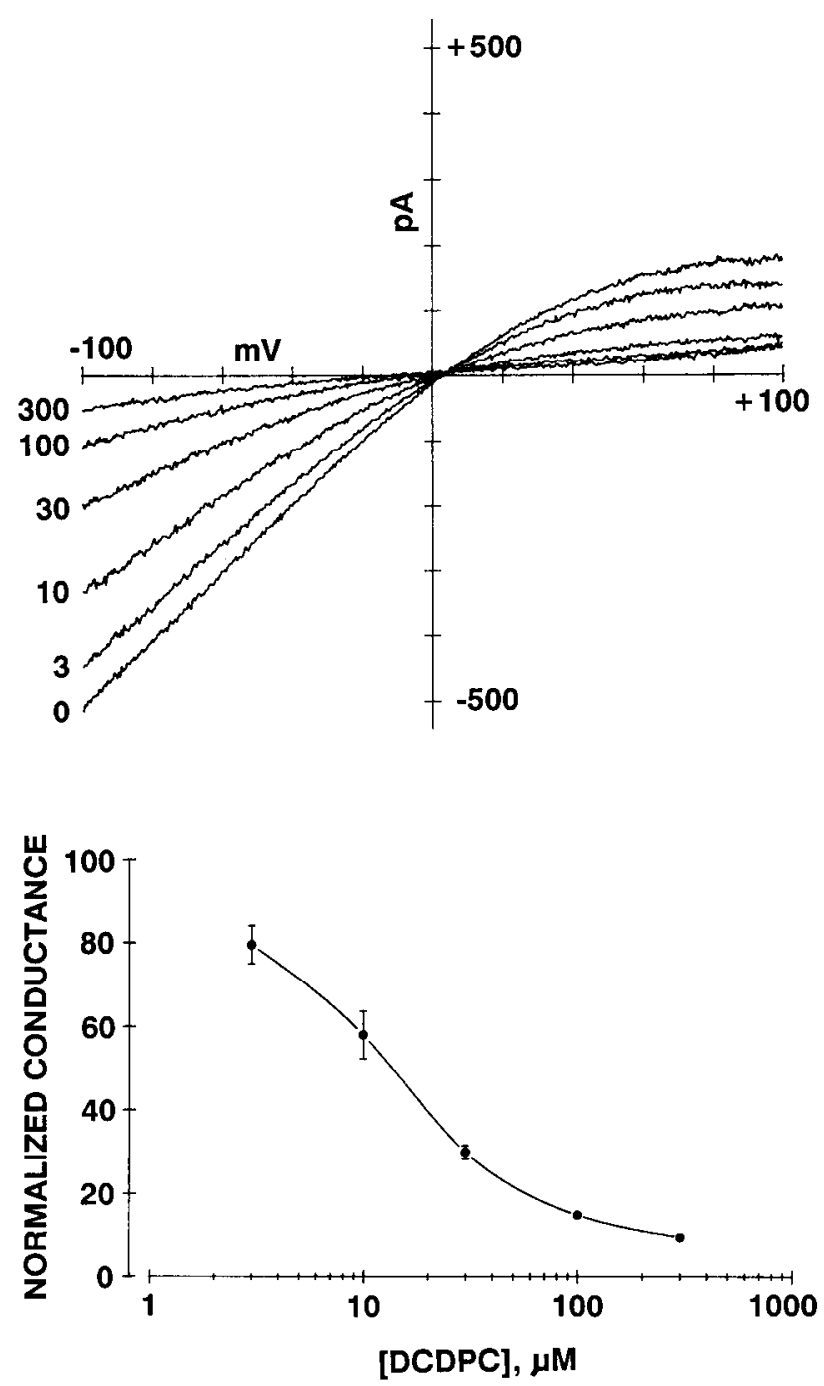

Figure 5. Inhibition of the $\mathrm{Ca}^{2+}$-activated current by DCDPC. Top, The current-voltage relationship of the ciliary membrane was measured in each of seven baths. The baths and recording pipette contained the cation-replaced versions of the pseudointracellular and extracellular solutions, respectively. The free $\mathrm{Ca}^{2+}$ and inhibitor concentrations in the first bath were 0; the other six baths contained $300 \mu \mathrm{M}$ free $\mathrm{Ca}^{2+}$ and from 0 to $300 \mu \mathrm{M}$ DCDPC as indicated. The $I / V$ curve in the first bath (not shown) was subtracted from the others so that only the $\mathrm{Ca}^{2+}$-activated current is plotted. Bottom, The slope of the current-voltage plot, measured in the linear range between -50 and $0 \mathrm{mV}$, is plotted against the concentration of DCDPC added. Each point is the mean \pm SEM of determinations in five cilia. Conductance in the absence of DCDPC was arbitrarily defined as 100 , and the other values were normalized to this. The maximum $\mathrm{Ca}^{2+}$-activated current (slope of the " 0 " curve between -50 and $0 \mathrm{mV})$ averaged $4.3 \pm 0.4 \mathrm{nS}(n=5$; range, $3.3-5.5 \mathrm{nS})$. The points were connected by cubic spline interpolation.

tance is inhibited by $\mathrm{Ca}^{2+}$ (Nakamura and Gold, 1987; Kolesnikov et al., 1990). We have not yet determined whether the $\mathrm{Ca}^{2+}$-activated increase in ciliary conductance occurs during the odorant response.

When the cilium is bathed by standard extracellular and pseudointracellular solutions, almost all of the current activated by cytoplasmic $\mathrm{Ca}^{2+}$ is carried by $\mathrm{Cl}^{-}$. Elimination of $\mathrm{Na}^{+}$and $\mathrm{K}^{+}$ does not significantly affect the $\mathrm{Ca}^{2+}$-activated current. We detected no single $\mathrm{Ca}^{2+}$-activated $\mathrm{Cl}^{-}$channels. Unit conductances of other $\mathrm{Ca}^{2+}$-activated $\mathrm{Cl}^{-}$channels have not been precisely determined but are reported to fall in the range of 1-23 pS (Mayer et al., 1990). The maximal $\mathrm{Ca}^{2+}$-activated $\mathrm{Cl}^{-}$current we observed would represent the opening of at least 150 such channels.

The $\mathrm{Cl}^{-}$current is half-maximal at a cytoplasmic $\mathrm{Ca}^{2+}$ concentration of about $5 \mu \mathrm{M}$, which is outside the usual dynamic range of $\mathrm{Ca}^{2+}$ concentrations in neurons $(0.1-1 \mu \mathrm{M}$; Blaustein, 1988). Half-maximal activation of ciliary adenylate cyclase by $\mathrm{Ca}^{2+}$ and calmodulin occurs at about $0.78 \mu \mathrm{M} \mathrm{Ca}{ }^{2+}$ in vitro (Anholt and Rivers, 1990). In catfish olfactory neurons, the intracellular $\mathrm{Ca}^{2+}$ concentration was never found to exceed $0.12 \mu \mathrm{M}$ (Restrepo and Teeter, 1990; Restrepo et al., 1990). This would be too little $\mathrm{Ca}^{2+}$ to activate the $\mathrm{Cl}^{-}$conductance we have found in frog olfactory cilia. However, the concentration of $\mathrm{Ca}^{2+}$ within the cilia has never been measured. Each cilium has a very large surface-to-volume ratio, so opening of $\mathrm{Ca}^{2+}$ channels on the ciliary membrane could result in very high levels of intraciliary free $\mathrm{Ca}^{2+}$. It has been similarly proposed that $\mathrm{Ca}^{2+}$ influx at presynaptic active zones might produce transient levels of free $\mathrm{Ca}^{2+}$ on the order of $100 \mu \mathrm{M}$ near the sites of secretion (Smith and Augustine, 1988). We have not determined if the $\mathrm{Ca}^{2+}$ activated conductance exists elsewhere on the neuronal surface.

The $\mathrm{Ca}^{2+}$-activated conductance shows nearly complete outward rectification at cytoplasmic $\mathrm{Ca}^{2+}$ concentrations of 1-2 $\mu \mathrm{M}$ (Figs. 1, 3). Thus, at these $\mathrm{Ca}^{2+}$ concentrations, the only $\mathrm{Cl}^{-}$ current possible would be a $\mathrm{Cl}^{-}$influx at positive potentials. This could help to repolarize the neuron after an odorant response, much as a $\mathrm{Ca}^{2+}$-activated $\mathrm{Cl}^{-}$influx repolarizes cone photoreceptors after action potentials (Maricq and Korenbrot, 1988). At higher cytoplasmic $\mathrm{Ca}^{2+}$ levels, the $\mathrm{Cl}^{-}$current becomes substantial at all potentials, showing moderate inward rectification at saturation. We do not know the origin of the rectification properties. They were not affected by replacing $\mathrm{Na}^{+}$ and $\mathrm{K}^{+}$on both sides of the membrane with choline ${ }^{+}$(compare Figs. 1 and 3 ).

Increases in $\mathrm{Cl}^{-}$conductance produce a variety of effects in other vertebrate neurons (reviewed in Alvarez-Leefmans, 1990). In some, opening of $\mathrm{Cl}^{-}$channels that interact with $\mathrm{GABA}_{\mathrm{A}}$ receptors hyperpolarizes the cell and generates IPSPs. Other neurons, including motoneurons and dorsal root ganglion cells in the frog, are depolarized by an increase in $\mathrm{Cl}^{-}$conductance. We cannot be certain how an increase in $\mathrm{Cl}^{-}$conductance might influence the cell potential of the frog olfactory receptor neuron. Olfactory cilia are bathed in mucus that has been found to contain $93 \mathrm{mM} \mathrm{Cl}^{-}$(Chiu et al., 1989). However, the $\mathrm{Cl}^{-}$concentration inside the cell has not been measured, and so the equilibrium potential for $\mathrm{Cl}^{-}$across the membrane of the neuron (or its cilia) is unknown. If the $\mathrm{Cl}^{-}$equilibrium potential is more positive than the resting potential, activation of the ciliary $\mathrm{Cl}^{-}$ conductance by an increase in intraciliary $\mathrm{Ca}^{2+}$ could help to depolarize the cell. If the $\mathrm{Cl}^{-}$equilibrium potential is near resting potential, the $\mathrm{Ca}^{2+}$-activated $\mathrm{Cl}^{-}$conductance would help to return the cell toward its resting potential after an odorant response.

\section{References}

Alvarez-Leefmans FJ (1990) Intracellular $\mathrm{Cl}^{-}$regulation and synaptic inhibition in vertebrate and invertebrate neurons. In: Chloride channels and carriers in nerve, muscle, and glial cells (Alvarez-Leefmans FJ, Russell JM, eds), pp 109-158. New York: Plenum.

Anholt RRH, Rivers AM (1990) Olfactory transduction: cross-talk between second messenger systems. Biochemistry 29:4049-4054. 
Bers DM (1982) A simple method for the accurate determination of free [Ca] in Ca-EGTA solutions. Am J Physiol 242:C404-C408.

Blaustein M (1988) Calcium transport and buffering in neurons. Trends Neurosci 11:438-443.

Breer H, Boekhoff I (1991) Odorants of the same odor class activate different second messenger pathways. Chem Senses 16:19-29.

Chiu D, Nakamura T, Gold GH (1989) Ionic composition of toad olfactory mucus measured with ion selective microelectrodes. Chem Senses 13:677-678.

DeLean A, Munson PJ, Rodbard D (1978) Simultaneous analysis of families of sigmoidal curves: application to bioassay, radioligand assay, and physiological dose-response curves. Am J Physiol 235:E97E102.

Firestein S, Darrow B, Shepherd GM (1991) Activation of the sensory current in salamander olfactory receptor neurons depends on a $G$ protein-mediated cAMP second messenger system. Neuron 6:825835.

Franciolini F, Petris A (1990) Chloride channels of biological membranes. Biochim Biophys Acta 1031:247-259.

Getchell TV (1986) Functional properties of vertebrate olfactory receptor neurons. Physiol Rev 66:772-818.

Gögelein H, Pfannmüller B (1989) The nonselective cation channel in the basolateral membrane of rat exocrine pancreas. Inhibition by 3',5-dichlorodiphenylamine-2-carboxylic acid (DCDPC) and activation by stilbene disulfonates. Pfluegers Arch 413:287-298.

Hagiwara S, Ohmori H (1982) Studies of calcium channels in rat clonal pituitary cells with patch electrode voltage clamp. J Physiol (Lond) 331:231-252.

Harrison SM, Bers DM (1987) The effect of temperature and ionic strength on the apparent $\mathrm{Ca}$-affinity of EGTA and the analogous $\mathrm{Ca}$ chelators BAPTA and dibromo-BAPTA. Biochim Biophys Acta 925: 133-143.

Huque T, Bruch RC (1986) Odorant- and guanine nucleotide-stimulated phosphoinositide turnover in olfactory cilia. Biochem Biophys Res Commun 137:36-42.

Kleene SJ, Gesteland RC (1991) Transmembrane currents in frog olfactory cilia. J Membr Biol 120:75-81.

Kolesnikov SS, Zhainazarov AB, Kosolapov AV (1990) Cyclic nucleotide-activated channels in the frog olfactory receptor plasma membrane. FEBS Lett 266:96-98.

Kurahashi T (1990) The response induced by intracellular cyclic AMP in isolated olfactory receptor cells of the newt. J Physiol (Lond) 430: 355-371.

Kurahashi T, Shibuya T (1990) $\mathrm{Ca}^{2+}$-dependent adaptive properties in the solitary olfactory receptor cell of the newt. Brain Res 515:261268.

Lancet D, Lazard D, Heldman J, Khen M, Nef P (1988) Molecular transduction in smell and taste. Cold Spring Harbor Symp Quant Biol 53:343-348.
Leveteau J, Andriason I, Trotier D, MacLeod P (1989) Role of divalent cations in EOG generation. Chem Senses 14:611-620.

Li M, McCann JD, Welsh MJ (1990) Apical membrane $\mathrm{Cl}^{-}$channels in airway epithelia: anion selectivity and effect of an inhibitor. Am J Physiol 259:C295-C301.

Maricq AV, Korenbrot JI (1988) Calcium and calcium-dependent chloride currents generate action potentials in solitary cone photoreceptors. Neuron 1:503-515.

Marks PW, Maxfield FR (1991) Preparation of solutions with free calcium concentration in the nanomolar range using 1,2-bis(o-aminophenoxy)ethane- $N, N, N^{\prime}, N^{\prime}$-tetraacetic acid. Anal Biochem 193:6171.

Mayer ML, Owen DG, Barker JL (1990) Calcium-dependent chloride currents in vertebrate central neurons. In: Chloride channels and carriers in nerve, muscle, and glial cells (Alvarez-Leefmans FJ, Russell JM, eds), pp 355-364. New York: Plenum.

Nakamura T, Gold GH (1987) A cyclic nucleotide-gated conductance in olfactory receptor cilia. Nature 325:442-444.

Restrepo D, Teeter JH (1990) Olfactory neurons exhibit heterogeneity in depolarization-induced calcium changes. Am J Physiol 258:C1051C1061.

Restrepo D, Miyamoto T, Bryant BP, Teeter JH (1990) Odor stimuli trigger influx of calcium into olfactory neurons of the channel catfish. Science 249:1166-1168.

Sato T, Hirono I, Tonoike M, Takebayashi M (1991) Two types of increases in free $\mathrm{Ca}^{2+}$ evoked by odor in isolated frog olfactory receptor neurons. NeuroReport 2:229-232.

Smith SJ, Augustine GJ (1988) Calcium ions, active zones and synaptic transmitter release. Trends Neurosci 11:458-464.

Suzuki N (1989) Voltage- and cyclic nucleotide-gated currents in isolated olfactory receptor cells. In: Chemical senses, Vol 1, Receptor events and transduction in taste and olfaction (Brand JG, Teeter JH, Cagan RH, Kare MR, eds), pp 469-493. New York: Dekker.

Trotier D, Rosin J-F, MacLeod P (1989) Channel activities in in vivo and isolated olfactory receptor cells. In: Chemical senses, Vol 1, Receptor events and transduction in taste and olfaction (Brand JG, Teeter JH, Cagan RH, Kare MR, eds), pp 427-448. New York: Dekker.

Tsien R (1980) New calcium indicators and buffers with high selectivity against magnesium and protons: design, synthesis, and properties of prototype structures. Biochemistry 19:2396-2404.

Wangemann P, Wittner M, DiStefano A, Englert HC, Lang HJ, Schlatter $\mathrm{E}$, Greger $\mathrm{R}$ (1986) $\mathrm{Cl}^{-}$channel blockers in the thick ascending limb of the loop of Henle. Structure-activity relationship. Pfluegers Arch 407[Suppl 2]:S128-S141.

Winegar BW, Rosick ER, Schafer R (1988) Calcium and olfactory transduction. Comp Biochem Physiol 91A:309-351. 